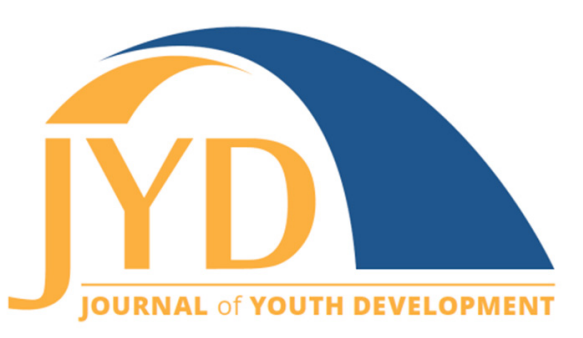

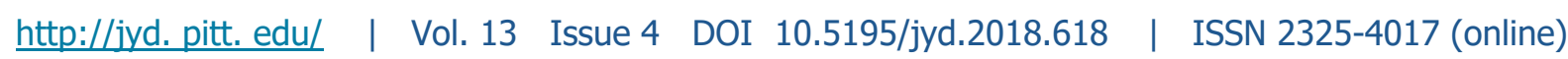

\title{
Curriculum Review: Relationship Smarts Plus 4.0
}

\author{
Alexander E. Chan \\ University of Maryland \\ alexchan@umd.edu
}

\begin{abstract}
The Relationship Smarts Plus curriculum contains 13 lessons regarding identity, principles of healthy dating, and communication skills. Lessons also include warning signs of abusive relationship and address the issue of intimate partner violence. At its core, the curriculum is built to teach youth how to realistically assess their real and potential dating relationships before making commitments or engaging in behaviors that may lead to unintentional commitments. This is a useful curriculum for educators seeking to engage a teen audience with research-informed activities in an area where teens have few sources of reputable information.
\end{abstract}

Key words: teens, relationships, dating

\section{Youth Relationship Education}

Youth development programs are obligated to ensure that their program offerings are in line with developmental needs of their audiences. The National Institute of Food and Agriculture (2015) suggests that 4-H Healthy Living programming should "provide developmentally appropriate learning opportunities that promote physical, social, and emotional well-being." Comprehensive studies of these programs suggest that as a whole, participants experience meaningful learning outcomes (Lerner et al., 2005; Lerner, von Eye, Lerner, \& Lewin-Bizan, 2009). However, attracting and retaining teen members remains a challenge for $4-\mathrm{H}$ programs (Hamilton, Northern, \& Neff, 2014; Harder, Lamm, Lamm, Rose, \& Lask, 2005). A promising avenue for attracting teen audiences is through the implementation of youth relationship education (YRE) programs.

\footnotetext{
(c)) EY New articles in this journal are licensed under a Creative Commons Attribution 4.0 License. This journal is published by the University Library System, University of Pittsburgh and is cosponsored by the University of Pittsburgh Press. The Journal of Youth Development is the official peer-reviewed publication of the National Association of Extension 4-H Agents and the National AfterSchool Association.
} 
Relationship Smarts Plus

YRE programs are designed to equip youth with the skills and knowledge necessary to make better choices about dating and romantic relationships. This is a developmentally appropriate task, as $70 \%$ of youth report having had a romantic relationship by age 18 (Carver, Joyner, \& Udry, 2003; Giordano, Manning, \& Longmore, 2010). Romantic relationships are also an important part of identity development, another prominent task of adolescence (Montgomery, 2005). However, there is often an absence of easily accessed, credible sources of information about relationships, leaving youth to consume this information from unreliable sources on the internet or television.

\section{Relationships Smarts Plus Curriculum}

One YRE curriculum that has an extensive and ongoing research base (Adler-Baeder, Kerpelman, Schramm, Higginbotham, \& Paulk, 2007; Kerpelman, Pittman, Adler-Baeder, Eryigit, \& Paulk, 2009; McElwain, McGill, \& Savasuk-Luxton, 2017) is the Relationship Smarts Plus curriculum (Pearson, 2013). The curriculum contains 13 lessons regarding identity, principles of healthy relationships, warning signs of abusive relationships, communication skills (both inperson and via social media), and sexual decision-making. The sexual decision-making material also covers the influence of substance use on the risk of contracting sexually transmitted infections.

Two initial lessons focus on building participants' awareness of their own strengths and weaknesses, as well as their goals for the future. Participants learn that romantic relationships can have a strong influence on their identity development, health, and even academic achievement (Giordano, Phelps, Manning, \& Longmore, 2008; Joyner \& Udry, 2000). Therefore, it is important to be aware of and nurture personal goals, independent of relationship involvement.

The majority of lessons highlight specific qualities of healthy relationships and how to develop these qualities with a partner. At its core, the curriculum is built to teach youth how to realistically assess their real and potential relationships before making commitments or engaging in behaviors that may lead to unintentional commitments (e.g., unplanned pregnancies). The lessons follow a temporal arc of relationship development, beginning with deciphering initial infatuation from love, followed by an examination of deeper issues such as effective conflict management and communication strategies. The influence of social media on dating receives an entire lesson of its own. One theme that appears throughout the curriculum is that of "decide, don't slide" into romantic relationships. 
This curriculum also addresses the issue of intimate partner violence. Teens are taught to recognize "red flags" of abusive relationships that may indicate a need to exit the relationship. For example, some content covers strategies on how to manage external pressure to cross a teen's pre-established sexual boundaries. Teens are also taught to distinguish clearly abusive situations from more ambiguous situations (e.g., isolated incidents of yelling during arguments) that may require further exploration before deeming the relationship abusive.

\section{Considerations for Youth Work Professionals}

The curriculum's design fits well with youth development programs such as 4-H that emphasize experiential learning. Each lesson contains both activity- and discussion-based elements. For example, the lesson regarding abusive relationships involves a game where participants race to pick up red and white flags off a table after hearing the instructor read a situation out loud. This comes early in the lesson, keeping true to the experiential do-reflect-apply process.

A limitation of this curriculum's use is the time required for training and preparation of facilitators. The lessons are scripted and provide plenty of background information. However, the discussion of romance with adolescent audiences is variable and can introduce unexpected elements into the program (e.g., challenging the sources of information, presenting contrary examples or stories, disclosing painful experiences). Program fidelity may be adversely affected if facilitators supply extracurricular information in response to unexpected participant questions. To avoid this liability, it is necessary for facilitators to rehearse and practice with a pilot audience comprised of volunteer youth or adults willing to take on the role of difficult youth (for a sample training model, see McElwain, et al., 2016). Supervision of new facilitators as they begin program implementation is also recommended.

Despite the training and supervision requirements, this curriculum presents vital information to an audience facing a dearth of reputable sources of information regarding romantic relationship development. Romantic relationships are a significant part of adolescent development and contribute to future relationship functioning (Furman \& Schaffer, 2003). It is well within the scope of youth development programs to offer this curriculum to teen participants. Relationship Smarts has been matched to national educational standards in health and family and consumer sciences, presenting an excellent opportunity for school enrichment as a mode of delivery. 


\section{Ordering Information}

The Relationship Smarts Plus curriculum is available in printed or online formats. The printed format costs $\$ 399$. The online format costs $\$ 199$ for a 1-year subscription or $\$ 399$ for a 3-year subscription. To learn more about Relationships Smarts Plus 4.0 and to order the curriculum, visit https://digital.dibbleinstitute.org/RQPLUS.

\section{References}

Adler-Baeder, F., Kerpelman, J. L., Schramm, D. G., Higginbotham, B., \& Paulk, A. (2007). The impact of relationship education on adolescents of diverse backgrounds. Family Relations, 56(3), 291-303. doi:10.1111/j.1741-3729.2007.00460.x

Carver, K., Joyner, K., \& Udry, J. R. (2003). National estimates of adolescent romantic relationships. In P. Florsheim (Ed.), Adolescent romantic relations and sexual behavior: Theory, research, and practical implications (pp. 23-56). Mahwah, NJ: Lawrence Erlbaum Associates.

Furman, W., \& Shaffer, L. (2003). The role of romantic relationships in adolescent development. In P. Florsheim (Ed.), Adolescent romantic relations and sexual behavior: Theory, research, and practical implications (pp. 3-22). Mahwah, NJ: Lawrence Erlbaum Associates.

Giordano, P. C., Manning, W. D., \& Longmore, M. A. (2010). Affairs of the heart: Qualities of adolescent romantic relationships and sexual behavior. Journal of Research on Adolescence, 20(4), 9831013. doi:10.1111/j.1532-7795.2010.00661.x

Giordano, P. C., Phelps, K. D., Manning, W. D., \& Longmore, M. A. (2008). Adolescent academic achievement and romantic relationships. Social Science Research, 371), 37-54. doi:10.1016/j.ssresearch.2007.06.004

Hamilton, S. F., Northern, A., \& Neff, R. (2014). Strengthening 4-H by analyzing enrollmentdata. Journal of Extension, 52(3), Article 3FEA7. Retrieved from https://www.joe.org/joe/2014june/a7.php

Harder, A., Lamm, A., Lamm, D., Rose, H., \& Lask, G. (2005). An in-depth look at 4-H Enrollment and Retention. Journal of Extension , 43(5), Article 5RIB4. Retrieved from https://www.joe.org/joe/2005october/rb4.php

Joyner, K., \& Udry, J. R. (2000). You don't bring me anything but down: Adolescent romance and depression. Journal of Health and Social Behavior, 41(4), 369-391. doi:10.2307/2676292

Kerpelman, J. L., Pittman, J. F., Adler-Baeder, F., Eryigit, S., \& Paulk, A. (2009). Evaluation of a statewide youth-focused relationships education curriculum. Journal of Adolescence, 32(6), 1359-1370. doi:10.1016/j.adolescence.2009.04.006

Lerner, R. M., Lerner, J. V., Almerigi, J. B., Theokas, C., Phelps, E., Gestsdottir, S., ... von Eye, (2005). Positive youth development, participation in community youth development programs, and 
Relationship Smarts Plus

community contributions of fifth-grade adolescents: Findings from the first wave of the 4-H Study of Positive Youth Development. Journal of Early Adolescence, 25(1), 17-71.

doi:10.1177/0272431604272461

Lerner, R. M., von Eye, A., Lerner, J. V., \& Lewin-Bizan, S. (2009). Exploring the foundations and functions of adolescent thriving within the 4-H Study of Positive Youth Development: A view of the issues. Journal of Applied Developmental Psychology, 30(5), 567-570. doi:10.1016/j.appdev.2009.07.002

McElwain, A., Finnegan, V., Whittaker, A., Kerpelman, J., Adler-Baeder, F., \& Duke, A. (2016). Evaluation and lessons learned from an undergraduate service learning course providing youth-focused relationship education. Evaluation and Program Planning, 58, 116-124. doi:10.1016/j.evalprogplan.2016.06.002

McElwain, A., McGill, J., \& Savasuk-Luxton, R. (2017). Youth relationship education: A metaanalysis. Children and Youth Services Review, 82, 499-507. doi:10.1016/j.childyouth.2017.09.036

Montgomery, M. J. (2005). Psychosocial intimacy and identity: From early adolescence toemerging adulthood. Journal of Adolescent Research, 20(3), 346-374. doi:10.1177/0743558404273118

National Institute of Food and Agriculture (2015). 4-H healthy living. Retrieved from https://nifa.usda.gov/program/4-h-healthy-living

Pearson, M. (2013). LoveU2: Relationship smarts PLUS. Berkeley, CA: The Dibble Institute. 